\title{
Introduction
}

The Middle East is currently undergoing the most dramatic transition since World War I. The crisis was unleashed by the Arab Uprisings (or 'Arab Spring') in 2010-2011, and is still (in 2017) unfolding in different violent and non-violent forms, from North Africa to the Gulf. What we witness in several parts of the Arab region is the implosion of states and state authority, leaving behind devastations, unprecedented suffering, and zones of power vacuum ready to be filled by non-state militias or external powers alike.

This book seeks to explore the condition of citizenship in the region as a core dimension of the crisis, a dimension that tends to be overlooked in the dramatic stream of events, also by academics. The Arab Uprisings brought to the surface a complex set of social, economic, and political grievances, but most of all a deep mistrust of citizens towards their own governments. The millions who occupied the streets in the early months of 2011 with demands of bread, dignity, and accountable government ignited an unprecedented crisis of legitimacy that threatened the local and regional political order. Locally, among most people, what happened is called a 'revolution'. Several rulers were indeed toppled, and modest reforms were achieved elsewhere, but the overall picture is currently that of counter-revolutionary forces hitting back mercilessly. Conflicts over the terms of citizenship understood as a social contract between rulers and the ruled are at the core of these developments and should be approached as such.

The variety of trajectories that the post-Uprising developments have taken clearly indicates a need for an open and multidisciplinary approach. Furthermore, the current crisis has wider regional ramifications that illustrate the contested nature of the state as the organising principle of political authority. The states and societies in the region, both Arab and non-Arab, are undergoing complex processes of transition, the outcomes of which are highly uncertain. The characteristics and historical patterns of Middle Eastern state formation are very different as compared with other regions, not least Europe. This invites a 'back to basics' approach in the analysis of the individual societies trapped in the crisis by keeping attention on how state-society relations have been formed; how ideas of 'citizen', 'nation', 
'state', 'community', 'authority', and associated concepts - and the relations between them - contribute to our understanding of the complex developments now unfolding.

Citizenship is the mechanism that binds together state authority and citizens under its jurisdiction; a bond of trust or mistrust, of loyalty or opposition, of solidarity or oppression. In the age of the nation-state and the universal norms of citizenship rights (as standardised in the 1948 Universal Declaration of Human Rights and the human rights conventions that followed), holding a citizenship is the key to legal protection and basic human rights. It is 'the right to have rights'; the fundamental organising principle of the modern state together with the principle of state sovereignty. ${ }^{1}$

The two principles of citizenship and sovereignty are closely related and balanced in the overarching idea of the modern nation-state. With sovereignty comes state obligations of guaranteeing and protecting the basic rights of every individual under the jurisdiction of the state, citizens as well as non-citizens. We know, of course, that this ideal model of the nationstate is not implemented on the ground in many parts of the world, not least in the Middle East, in spite of the monitoring mechanisms of the UN organs and regional mechanisms on behalf of the international society. The balance between the two principles is in fact leaning heavily in favour of sovereignty and the associated principle of non-interference in internal affairs of the state, making it possible for the most notorious dictatorships to remain members of the UN with impunity and leaving their subjects in a very vulnerable and unprotected position. Persons without citizenship, stateless individuals, and those who have had their citizenship revoked for one reason or another, are in a particularly severe position, often as non-existent in any public records and without access to public services, to a passport, a bank account, etc.

The hypothesis of the project behind this book is not that there is one common pattern of state-citizen relations to be found throughout the Middle East; on the contrary, we seek to explore the variety of traditions and legacies, of state formations, regimes, and ideologies that form the overall picture of the region today. ${ }^{2}$ However, one common denominator

1 See Asbjørn Eide, 'Citizenship and International Human Rights Law,' in Citizenship and the State in the Middle East: Approaches and Applications, eds. Nils A. Butenschøn, Uri Davis, and Manuel Hassassian (Syracuse: Syracuse University Press, 2000) 88-123.

2 The project was initiated by the editors of this book with a call for an international conference, 'Arab Citizenship in the New Political ERA', hosted by Université Mohammed V, Rabat-Souissi in May 2014. The first book from the 
that makes it meaningful to study the Middle East as a crisis-ridden region is the unresolved and deeply entrenched divergences in the views of state authority and the social contract between rulers and the ruled. In short, it is the state itself as a sovereign organisation of territorial communities that is in crisis. Whereas the crisis is most exposed in the Arab part of the region, it is not limited to the Arab countries; also the Iranian theocracy, the Israeli ethnocracy, and the Turkish autocracy are states facing deepseated challenges that should be studied through the lens of citizenship.

On another level, the centrality of citizenship related to the Middle East was underlined during the wave of refugees entering the EU in the summer of 2015 in search of refuge and possibly a new life as citizens of a European country. What they were hoping for in Europe was access to safety, protection, work and education, and to enjoy the rights of freedom of speech, belief and organisation. At the same time, we saw the reverse movement: Muslim youth from the United States and the EU travelling to join the Islamic State in Iraq and Syria (ISIS), where they acquired a new status as foreign fighters and demonstratively burnt their passports in a show of contempt of the secular states they believe are illegitimate and not ruled according to 'what God has sent down'. Or worse, reneging on their citizenship by executing attacks on citizens in the countries where they lived. ${ }^{3}$ In addition, as hundreds of thousands of refugees entered Europe, established conceptions of citizenship in the European setting were also challenged and came to the forefront of political struggles there. Who is to be included, on what grounds and which conditions, to what extent and for how long?

Given this background it is surprising, for several reasons, that citizenship as a separate factor seldom figures in the debate on the crisis in the Middle East. In some of the recent important books published on the politics in the region citizenship is hardly mentioned. Factors relevant to citizenship such as authoritarianism, bad governance, poverty and other dimensions of underdevelopment are certainly discussed, but the political dynamics of citizenship as an important factor explaining the political crises in these countries are, in our opinion, not given sufficient, if any, attention. ${ }^{4}$ Nor does citizenship play a significant role in Islamic studies. Authors mostly concentrate on identity, values, piety, norms, Islamic law,

project was The Crisis of Citizenship in the Arab World, eds. Roel Meijer and Nils Butenschøn (Leiden: Brill, 2017).

3 Peter M. Berger, The United States of Jihad: Who Are America's Homegrown Terrorists and How Do We Stop Them? (New York: Broadway Books, 2016).

4 Vincent Durac and Francesco Cavatorta, Politics and Governance in the Middle East (London: Palgrave, 2015); John Chalcraft, Popular Politics in the Making of the Modern Middle East (Cambridge: Cambridge University Press, 2016). 
political Islam and social movements, but how these factors relate to such a crucial issue as citizenship and what that entails remains mostly unclear. This is all the more surprising as all Islamic thought in one way or another addresses substantive issues of citizenship, either by rejecting the statecentred conception of citizenship (as the alternative idea of "citizens of God' in Salafism), or making citizenship in fact a central issue, but recognising it only in such terms as the 'common good' or 'promoting the good and preventing evil', or the 'rights of God'. In many ways, as elaborated elsewhere, elements of modern citizenship can be built on already existing Islamic thought and Islamic law. ${ }^{5}$

Furthermore, a broader awareness of the centrality of citizenship in the aftermath of the Arab Uprisings could have been expected when we consider how the study of citizenship rose to prominence in connection with the dramatic transitions in Europe after the dissolution of the Communist states in Eastern Europe in the early 1990s. In many ways this situation compares well with the current crisis in the Middle East as illustrated when Ronal Beiner explains the significance of the citizenship approach to the European crisis:

These [European] political crises ... are indeed central to an understanding of why the problem of citizenship is especially salient in our day. Ethnic and sectarian conflict in northeastern and southeastern Europe; a redefining of national states at the heart of Europe, in a post-Cold War epoch that might have been expected to diminish political turbulence but seems instead to have generated more of it; dislocating shifts of identity provoked by mass migration . . . All these political dilemmas have raised anew deep questions about what binds citizens together into a shared political community. To these formidable challenges may be added what is probably the greatest challenge of all to contemporary citizenship, namely, persistent mass unemployment, which offers the surest prospect of excluding tens of millions of people ... from a sense of full membership in civic community. ${ }^{6}$

\section{THE CITIZENSHIP APPROACH}

Analytically, the citizenship approach, whether applied to Europe or the Middle East, is located at the level in between the state/ruler (top down) and the individuals or group of individuals under the jurisdiction of the

5 See Part II in this volume. See also Knut Vikør, 'Muslim Subjects and God's Law,' in The Crisis of Citizenship in the Arab World, eds. Roel Meijer and Nils Butenschøn (Leiden: Brill, 2017) 273-95.

6 Ronal Beiner, 'Introduction: Why Citizenship Constitutes a Theoretical Problem in the Last Decade of the Twentieth Century' in Theorizing Citizenship, ed. Ronal Beiner (New York: State University of New York, 1995), 3. 
state (bottom up). The aim is to identify and understand the dynamics of the interaction between the two levels as it can be studied both in terms of structural characteristics (laws and institutional frameworks, economic factors, cultural patterns) and agency (individual or collective strategic behaviour). Keith Faulks has suggested a useful categorisation of three main dimensions of citizenship: Extent (who are included in/excluded from membership in the political community; content (which rights and obligations are covered); depth (the level of commitment by the parties to citizenship as a social contract). ${ }^{7}$ The citizenship approach should basically be seen as a method, not as a theory (even if there are theories about citizenship); it is an analytical approach that is context specific and applicable within different disciplines (social sciences, the humanities, law). It is well suited for comparative studies across empirical cases and, consequently, for theory development within individual disciplines. But it is not a discipline in itself. With this in mind this multidisciplinary book includes a number of case studies of countries and context specific issues that we consider to be of particular relevance, but certainly not exhaustive, in the study of the current crises - both in Arab and non-Arab parts of the Middle East and North Africa.

The case studies that follow are set in the general framework that includes a number of background issues, such as patterns of modern state building in the region; colonial legacies; identity formation and political loyalties; state sovereignty and transnational ideologies; and geopolitics.

\section{CITIZENSHIP AND STATE FORMATION IN THE MIDDLE EAST}

With the emergence of the modern state in the Middle East and North Africa from the beginning of the nineteenth century the significance of citizenship became progressively more apparent. This was an effect of the rise of the new relationship between state and society, the standardisation of bureaucratic procedures, the increased demands of the state on the population in the form of loyalty and the imposition of duties (taxes, conscription, education, identity, norms and values, political participation). The Tanzimat reforms (1839-1876), the rise of Ottomanism as a common identity and shared equal rights, as well as the struggle for independence of former Ottoman lands, cannot be understood without notions of citizenship and drawing literal and imaginary boundaries between those

7 Keith Faulks, Citizenship (Abingdon: Routledge, 2000), 7. 
who belong to the body politic and those who do not. This process was diffuse, highly irregular, constantly taking different shapes, particularly in certain countries and periods, fluctuating between collective and individual rights, and subsumed in different forms of unspoken pacts, or social contracts. ${ }^{8}$

The current crisis of the state in the Middle East has direct links to patterns of state formation under the influence of the Ottoman Empire and later colonial rule and geopolitical rivalries in the region. In the course of the breakdown of the Ottoman Empire and the struggle for territorial control among Western powers, the new states were established in several waves. The first wave was started in the early nineteenth century and ended in 1923 with the Treaty of Lausanne. At that point most of the region except for Turkey was under direct or indirect control of the colonial powers. The new states emerging from the post-World War I diplomacy had their borders, constitutions, and rulers to a large extent decided in uneven bargaining processes between colonial centres and local elites.

The new boundaries destroyed social, economic and cultural relations which had existed for centuries in empires whose boundaries were fluid. All at once a city like Aleppo found itself cut off from its hinterland and subordinated to Damascus. Aleppans had to find a new identity and identify with Arab nationalism and hate 'Turks', which was utterly strange to them. Turkish speaking members of the Greek Orthodox Church were subjected to forced emigration to Greece because they were regarded as Greeks. Kurds were dispersed over four countries: Syria, Turkey, Iraq and Iran, and in all these countries their identity was suppressed. Bedouin found themselves unable to reach their grazing grounds on the other side of a border. Arab Palestinians found themselves basically excluded in the British League of Nations mandate, when Palestine in 1922 for the first time was organised as a separate state territory. The provision in the Mandatory Regulations that a 'national home for the Jewish people' should be established in the country was unacceptable to the indigenous population, making it impossible for them to participate in the running of the country without undermining their claim to self-determination. ${ }^{9}$

8 See, for example, Stanford J. Shaw and Ezel Kural Shaw, History of the Ottoman Empire and Modern Turkey. Volume II. Reform, Revolution, and Republic: The Rise of Modern Turkey, 1808-1975 (Cambridge: Cambridge University Press, 1977).

9 See Nils A. Butenschøn, 'The Paradox of Palestinian Self-determination' in Where Now for Palestine? The Demise of the Two-State Solution, ed. Jamil Hilal (London, New York: Zed Books 2007), 75-99. 
Shi is in south of the Arabian Peninsula and the Hejaz found themselves in the new kingdom of Saudi Arabia. ${ }^{10}$ With boundaries and the demand for loyalty, and new duties, 'majority' citizens were created with full rights and secondary citizens, or residents without rights created.

The second wave in the 1960s and 1970s saw the establishment of the Gulf states (from Kuwait in 1960 to the United Arab Emirates in 1970) after the British left, and a new definition of who were members and who were not took place. In between, several attempts were made, under the banner of Arab nationalism, to change borders imposed under colonial rule, such as the United Arab Republic (UAR) of Syria and Egypt 1958-1961 and other short-lived attempts to unify Syria and Iraq (1965) and Libya and Egypt (1971). ${ }^{11}$

On a parallel track, the State of Israel had been established in 1948, triggering the first Arab-Israeli war and making the previous British mandate into a continuous war zone. To top it off, theoretically Israel's potential citizens as defined by the Zionist state idea included world Jewry under the Law of Return issued in 1950, excluding Palestine's non-Jewish Arab population from full membership in the political community, and over the years preventing millions of refugees from returning to their homes. With its conquest of the rest of mandate Palestine under the Six Day War in 1967, what is known as the 'ingathering of the exiles' suddenly became a more realistic option, defining the Israel-Palestine conflict ever since. ${ }^{12}$

\section{THE SOVEREIGN AND SOVEREIGNTY}

The location of sovereignty is also not always clear. In monarchies it lies with the monarch or the royal family, who embody sovereignty, much as the French King embodied the state. The patrimonial 'l'état c'est moi' still applies to most monarchies in the Middle East. Citizenship is a gift (makrama) that can be bestowed and rescinded at will, as Zeineb Alsabeehg

10 Toby Matthiesen, The Other Saudis: Shiism, Dissent and Sectarianism (Oxford: Oxford University Press, 2015).

11 For a well-known study of the early attempts, see Malcolm Kerr, The Arab Cold War: Gamal Abd-al Nasir and His Rivals 1958-1970 (London: Cambridge University Press, 1971).

12 The so-called Jerusalem Program, adopted as the platform of the World Zionist Organization in 1968, defined ' $[\mathrm{t}]$ he ingathering of the Jewish people in the historic homeland, Eretz Israel, through aliyah [immigration] from all countries' as its central task. The New Jerusalem Program adopted in 2004 contains effectively the same provision. See http://www.wzo.org.il/The-Jerusalem-Program, accessed 3 May 2017. 
shows in the example of Bahrain in this volume. Where the monarchy has evolved and moves in the direction of a constitutional monarchy, as is the case of Morocco, a hybrid form exists, as is expressed in the paradoxical term of Mohammed VI, who calls himself the 'citizen-king' (le roi citoyen), very much reminiscent of Louis Philippe in France (1830-1848). In this volume Mariwan Kanie demonstrates that even republican Iraq under Saddam Hussein fell back on this tradition, after the 1991 defeat, giving the country a modern authoritarian streak.

Sovereignty in other republics, however, is also not always clear. In many cases sovereignty is mediated. In Egypt, the Coptic Church is such an intermediary between the state and its religious followers. In Lebanon, the state is subjected to these mediators who determine the power/weakness of the state and divide its sovereignty among each other proportionally. In regions where tribal structures are still strong, as in Saudi Arabia or Jordan, tribes are maintained as intermediaries and held responsible for the conduct of their members. The religious establishment is another intermediary. In other cases, the creation of such mediators is a way to maintain the power of the state and co-opt civil society and exert patronage. One example is the cultural centre for the Amazigh minority in Morocco, officially controlled by the monarchy. ${ }^{13}$

\section{CITIZENSHIP AND TRANSNATIONAL IDEOLOGIES}

Sovereignty of the state has not been helped by the prevailing ideologies in the Middle East. Islamic political philosophy has never been very strongly developed and remained subordinated to religion. The Ottoman sultans developed administrative law, but that was to enhance the power of the state. There did exist a concept comparable to citizenship and notions of what can be called a Rechtsstaat in Islamic law. Otherwise the millet system supported a system of intermediaries who were largely autonomous but responsible for their community. The communitarian dimension was further enhanced by colonialism, which introduced systems of divide and rule in Lebanon, Syria, Iraq and Morocco. The subsequent nationalist ideologies in the era of anti-colonial liberation expanded the community from religious community to national, ethnic community, without developing individual rights, which are so crucial for citizenship. Especially influential has been the near universal retention of religious personal

13 Francesco Cavatorta, 'Divided They Stand, Divided They Fail: Opposition Politics in Morocco’ Democratization 16 (2009) 1: 137-56. 
statute and family law, which has made civil marriage impossible in the region and has hampered equality and cross-sectarian marriages. PanArabism was too wide to enhance individual rights. Syrian movements in favour of Arab unification, including the Ba'ath party, did not produce a well-defined citizenship. Roel Meijer demonstrates in this volume a similar tendency within Islamist movements such as the Muslim Brotherhood and Salafism. Even where Sayyid Qutb's submission to God's sovereignty did allow for an opening up of the possibility of revolt against the state and agency, it did not lead to individual rights. A concept of the sovereignty of the people was finally developed, but this was ambivalent and retained strong sectarian overtones.

\section{THE DEMOGRAPHIC FACTOR}

A sign of weak sovereignty and legitimacy and the existence of many different unintegrated ethnic and religious minorities or even majorities has politicised demographic data. This is not abnormal and occurs in all countries. But nowhere are demographic data as sensitive and part of state security as in the Middle East. To a large degree the politics of citizenship concerns demographic management (with reference to Keith Faulks' 'extent of citizenship'-dimension mentioned above). The delicate balance between groups, the percentages of residents who as citizens could make claims are notorious. It has added significance to citizenship as a central dimension in Middle Eastern politics. Examples include the ethnocratic nature of the State of Israel, based on the premise of political hegemony of Jews as discussed by Nils Butenschøn in this volume. Demography, in particular the Jew/non-Jew ratio, represents a 'ticking bomb' under the current political system. Demography is also a core issue in the fragile power-sharing arrangement between Christians and Muslims that has regulated the Lebanese political system since independence. The National Pact of 1943 is a political contract between family-dominated religious sects based on the last census held in 1932. The 1990 Constitution that ended a 15-year civil war revised only moderately the system that had guaranteed Christian dominance in favour of the Muslims, indicating that the Lebanese are still not ready to dissolve the sectarian nature of the political system and establish a unified citizenship. ${ }^{14}$ Moreover, the demographic factor will undoubtedly play a central role in the future

14 See for example, Nils A. Butenschøn, Øyvind Henden, and Kåre Vollan, 'Lebanon' in Power-Sharing in Conflict-Ridden Societies: Challenges for Building 
political organisation of the war-ridden countries of Iraq and Syria (Who should be included in what arrangements, and where?). The position and role of the Kurds is a particularly salient question that will influence the integrity of these states and stability of the regional order.

Bahrain is another affected country. As Zeineb Alsabeehg makes clear in this volume perhaps as many as 200,000 Sunnis have been given Bahraini citizenship in order to turn the demographic balance between Sunnis and Shi is in that country.

\section{CITIZENSHIP, AGENCY AND EMANCIPATION}

Societies seldom develop in one direction only. Despite the forces working against equal citizenship, citizenship as a concept has gradually penetrated the public domain in the region. It is not difficult to identify parallel and conflicting tendencies, some pointing towards further disintegration of societies, public trust, and integrity of states, others pointing towards a higher awareness of social responsibility and active citizenship. In spite of immense setbacks this is made clear in the long-term perspective. Although the state's sovereignty might be marred by porous borders, intermediary institutions, communitarianism, collectivism, demographic disparity, ethnic and sectarian discrimination and exclusion, pervasive patronage, police repression, and deficient social contracts, notions of citizenship took hold already from the early nineteenth century. Later, with increasing demands made by states upon their subjects, identities also changed, and people formulated counter demands. With the emergence of the public sphere, people read newspapers, participated in political movements, became connected and started to live in 'imagined communities', which also meant they were citizens and could identify beyond their community, tribe, clan, religion, village and region. ${ }^{15}$ They no longer mobilised only along tribal lines, but also based on professional identities and economic interests. Traditional Islamic notions changed character and became 'infected' by terms and concepts derived from the West, giving them a more abstract content adapted to the emergence of the citizen. Concepts such as reform and the common good indicated a change in the relations between state and subject, inferring a modern relation between

Peace and Democratic Stability (Farnham and Burlington: Ashgate, 2015), 105-135.

15 Armando Salvatore and Dale F. Eickelman, Public Islam and the Common Good (Leiden: Brill, 2004). 
citizen and state based on a negotiated social contract with the state working to the benefit of the citizen and the citizens having a responsibility to the larger good than his/her own community. It contained new notions of law, the position of women, the status of children, the role of education, and national economy, national and personal welfare.

Such patterns of modernisation were identified by Middle East scholars already in the 1950s and 1960s and led to general expectations that modernisation would continue to dominate the social, economic, political and cultural development, bringing Middle Eastern societies closer to the European patterns of development. ${ }^{16}$ The tribal, patrimonial and sectarian traits typical of the traditional society would vanish together with personalised monarchical political systems. These expectations were not unreasonable at the time, particularly under the impression of the forceful mobilisation of Arab socialism that inspired millions across the region. But again, the counter-forces were strong, trapping the region in an 'iron triangle' whereby international, regional and local actors formed formal or informal alliances in order to secure that radical forces and threats to the regional order and interests of world powers would be neutralised (a pattern not very different from what we have observed in the current post-Arab Spring era). ${ }^{17}$

\section{INCREASED AWARENESS OF CITIZENSHIP}

What is clear is not only that citizenship is central but also that its forms fluctuate and its public prominence differs. Contesting unjust citizenship regimes can be done in many ways, based on different ideologies, concepts and notions, both in formal ways and informal ways. Informal political networks access the alternative avenues of participation and try to affect the distribution of goods and power relations. ${ }^{18}$ Notions of citizenship can penetrate existing relations of power and subvert them and inspire change in relations of dependency. ${ }^{19}$ Informal rights and concealed

16 See for example, Daniel Lerner, The Passing of Traditional Society (Glencoe: Free Press, 1958); Manfred Halpern, The Politics of Social Change in the Middle East and North Africa (Princeton: Princeton University Press, 1963).

17 See Nils Butenschøn, 'The Arab Spring and the "Iron Triangle": Regime Survival and the Conditions of Citizenship in the Arab Middle East' in The Crisis of Citizenship in the Arab World, eds. Roel Meijer and Nils Butenschøn (Leiden: Brill, 2017) 246-69.

18 Diane Singerman, Avenues of Participation: Family, Politics, and Networks in Urban Quarters of Cairo (Princeton: Princeton University Press, 1989).

19 Ward Berenschot, Henk Schulte Nordholt and Laurens Bakker (eds.), Citizenship and Democratization in Southeast Asia (Leiden: Brill, 2017). 
notions of justice can express themselves in many ways ranging from 'quiet encroachment of the ordinary', ${ }^{20}$ to what has been called 'everyday citizenship', ${ }^{21}$ and 'acts of citizenship', ${ }^{22}$ which are less organised and not always developed in relation to the state. Over time these can develop into social movements and even into political parties, transitioning from informal networks to formal organisations, with the danger that they lose their original purpose and become incorporated and depoliticised. ${ }^{23}$

We notice waves of increased awareness of citizenship in the beginning of the nationalist movement prior to Arab independence; Arab socialism 1950s to the 1970s; The Berber Spring 1981; the Palestinian Intifada 1987-1993; the Iraqi Intifada 1991; the Arab Uprisings 2010-2011.

What is crucial is that these developments highlight the importance of agency and the influence people have on the content, extent and depth of citizenship. They indicate a political awareness, conceptualisation of rights and notions of justice, and an increased self-reflexivity and attentiveness to the political environment. In this process, practices and concepts influence each other in ways that give hope for the future, even if the counter-forces such as those executed by the state and non-state actors on the national and local level in the form of patronage, repression, encapsulation and co-optation are always present as a threat.

What these examples further demonstrate is that the citizenship approach brings together not only the different conceptual dimensions of political authority, but also a wealth of experiences on the global, regional, and local levels that have, or should have, important policy implications. International standards of governance are centred on human rights, good governance, and the rule of law. These are universal norms and rules which are often at odds with the situation at hand. Their character as legalistic, formal, and procedural often makes them appear as external to the population and the values they uphold and practices they and local governments follow. They are a yardstick to measure 'progress' and 'regression' and compliance with external standards. But this tension between the external standards and the experienced world so often observed, this fundamental

20 Asef Bayat, Making Islam Democratic: Social Movements and the PostIslamic Turn (Stanford: Stanford University Press, 2007).

21 Salwa Ismail, Rethinking Islamist Politics: Culture, the State and Islamism (London: I.B. Tauris, 2003).

22 Engin F. Isin and Greg M. Nielsen, Acts of Citizenship (Chicago: Chicago University Press, 2008).

23 As, for instance, happened with the Justice and Development Party (PJD) in Morocco. The failure of the Arab Uprisings is ascribed to the failure of this transition. 
entfremdung, makes it difficult to identify mechanisms for effective realisation of the internationally accepted standards. The citizenship approach, in contrast, starts at, or at least delves into, the practices and notions of people themselves, their specific local forms, histories, cultural, political and economic environment and the national and international influences which have impinged on a specific citizenship regime. This does not mean that the citizenship approach neglects these international standards. It includes them because they all entertain and promote a certain concept of citizenship.

While some people support good governance, human rights, and the rule of law, all people and institutions entertain and affect notions and follow practices of citizenship. To discover what these are, which legal, social, economic, political, and ideological factors influence them, goes to the heart of politics. It analyses the 'actual situation' not the ideal situation and what is supposed to be.

\section{CONTRIBUTIONS}

We will use the distinctions Keith Faulks has suggested between three dimensions of citizenship rights - extent, content, and depth - to analyse the chapters of this volume and draw out their common themes. ${ }^{24}$ Extent refers to the issue of who belongs to the community, and on what terms; content refers to rights of access to the services of the state; depth refers to what is demanded of members in the form of responsibility, participation and solidarity. These three dimensions cover crucial aspects of citizenship.

In Chapter 1 Nils Butenschøn argues that the citizenship approach is sufficiently open in its theoretical orientation and precise enough as an analytical tool to capture the complexities of Israel as a state formation, and yet identify the distinct challenges this state poses in its relations with the various demographic collectivities that have claims to the territories under its current rule or control. The nature of these challenges and the controversies and conflicts they have sparked since the establishment of the state in 1948 can only be fully comprehended with a view to the extent, content and depth of citizenship as premised by Zionism as its ideological foundation and the historic conditions for creating a separate state for Jews in Palestine. Presenting some of the main academic discourses on Israel as an 'ethnic' state, 'democratic' state, and 'Jewish' state, Butenschøn maintains that whereas the legal and institutional fabric of the

24 Faulks, Citizenship. 
State of Israel unquestionably is ethnocratic in distribution of rights and resources, the state itself is still a state in the making, an unfinished state (by default, just like Palestine). This relates to the fact that neither its final borders nor the citizenship implication of its identity as a 'Jewish' state have been defined, leaving strings of controversies in relation to secular and religious Jewish societies and denominations, both locally and globally, as well as in relation to the Palestinians living in the State of Israel and in the Occupied Palestinian Territory, and the millions of refugees in exile. The larger picture is that of a state established against local and regional resistance, a state 'in the Middle East, but not of the Middle East' basing its survival on military hegemony; a 'programmatic' state seeking to integrate world Jewry but not the local non-Jewish population, gradually expanding its hold on Mandatory Palestine. This is the dynamic of a frontier state based on expanding ethnically exclusive settlements in conquered territory; in the contemporary world a unique challenge to the local, regional, and international order.

Chapter 2, by Basak Ince, is a good illustration of the changing character of citizenship and how it is influenced by internal and external dynamics in Turkey. She demonstrates how during the 1980s the secular and uniform concept of citizenship which Atatürk had imposed in the 1930s with its emphasis on duties and Turkish identity gradually became more pluralistic, recognising difference and becoming more receptive to the specific identities of Alevis, Kurds, and other minorities. In the words of Bryan Turner, 'formal', state definitions of citizenship were being replaced by 'radical' concepts of citizenship influenced by the people. With this move the emphasis changed from the legal aspect (extent of citizenship) to identity (content) and 'civic virtue' (depth). The last is represented by civic education and instilling in children notions and practices of equal citizenship. In this period Alevis, Christians, Jews, and Kurds demanded recognition of their religious institutions, freedom of religious education and equal access to the same funds of the state as the majority Sunni population. These changes were gradually put into practice after the Justice and Development Party (AKP) came to power in 2002. They were incorporated in its elections programme of 2007 and recognised as fundamental rights of citizens in constitutional amendments. In hindsight the draft Constitution of 2007 proved to be the high point of this trend. Since the Arab Uprisings and especially after the attempted coup in summer 2016 Turkey has drifted towards an authoritarian citizenship regime based on a populist, controlled, communitarian and deeply Turkish nationalist notion of citizenship.

If Turkey was largely successful in imposing concepts of citizenship from above, although Atatürk's legacy concerning extent, content, and 
depth of citizenship is still being contested, Iraq, as analysed in Chapter 3 by Mariwan Kanie, represents a state where all attempts by the state to create a homogeneous population failed. The major difference was that Iraq did not emerge from a successful revolution and did not have a military leader who saved the country from occupation, as was the case in Turkey during the war of liberation (1920-1923). Iraq was also a more fragmented society between Shi is, Sunnis, Kurds and different Christian denominations, as well as smaller minorities such as Assyrians, Turkmen, Jews and Yezidis. Another difference was that Sunni leaders managed to retain power until the Americans invaded Iraq in 2003 and a dramatic shift took place in favour of the Shi' is. As a result, the Sunni elite could pursue assimilationist policies as expressed in Sati 'al-Husri's pan-Arab educational project and forcefully repress the Kurdish and Shi i identity. The resistance against Sunni dominance continued throughout Iraq's modern history. The Communist Party of Iraq was one of the few political currents that embraced an active, participatory citizenship based on ethnic, religious, gender and social equality as well as cultural pluralism. After a brief period in the 1950s of widely supported social contract between the different ethnic groups in society, in the 1970s Saddam Hussein introduced a new phase of brutal repression of Pan-Arabism. Kanie gives an extensive analysis of the efforts of the $\mathrm{Ba}$ 'ath state to destroy any notion of rights and install a regime based on total fear and powerlessness of the citizen. In the end, the only thing that counted was loyalty to Saddam. No wonder that after the American invasion notions of shared citizenship hardly existed and fissures in society along ethnic and religious lines deepened. The establishment of ISIS in 2014 is a direct result of the failure of the Nouri al-Maliki government (2006-2014) to establish an inclusive, egalitarian but pluralistic citizenship regime. ${ }^{25}$ In that context, it was not illogical that Sunni Iraqis tried to establish a homogeneous religious state based on Sunni religious exclusivity.

In Chapter 4 Sylvia Bergh and Salima Ahmadou analyse the discourse of former members of the February 20 Movement in Morocco in relation to the concept of citizenship. Citizenship had been one of the central concepts of the February 20 Movement in 2011, which demanded equal civil, political and economic rights at the expense of the power of the Makhzen (power structures around the monarchy), condemning corruption, marginalisation and deprivation of dignity (hogra). As none of the grievances of the Arab Uprisings have been addressed, citizenship

25 Toby Dodge, Iraq: From War to a New Authoritarianism (London: The International Institute for Strategic Studies, 2012). 
continues to be the central demand after 2011, as is apparent from the Rif Uprisings and elsewhere in 2017. One of the reasons for the common theme of citizenship is that in Morocco, like in Tunisia, cross-ideological coalitions were formed between leftist, Islamist and non-political groups which had worked together in protest committees (tansiqiyyat). They express their grievances in 'acts of citizenship', in the form of 'taking to the street', 'freeing public space', and organising debates on public issues such as rising prices, corruption, profit of private investors and social justice. Learning from the failures of the February 20 Movement, activists pay more attention to defining more clearly the extent, content and depth of citizenship and formulating more concrete demands. The connection they make between socio-economic development and political citizenship reflects their increased political awareness. It is the arbitrariness of the authorities and their treatment as 'subjects' that provokes the greatest outrage.

In Chapters 5 and 6 Zahra Babar and Zeineb Alsabeehg underline the centrality of citizenship for understanding core political dynamics in the Gulf states. Contrary to what is normally assumed by proponents of the so-called rentier state model, citizens in the Gulf are not passive but try actively to influence the extent, content and depth of citizenship in their own countries. Whereas it is well known that these oil-rich monarchies have 'bought' political loyalty by providing privileged citizens with basic social and economic needs through government stipends, subsidies, job guarantees, free education and health care, giving incentives for political inactivity and leaving legislative assemblies toothless (except in the case of Kuwait), this kind of social contract has been rejected by important segments of the population. They show that political contestation has always existed, and, in fact, has grown since the Arab Uprisings and that citizenship rather than democracy is central to that political struggle. The difference with liberal democracies is that illiberal states do not have formal channels for political contestation that are not under the control of the regime and that contestation assumes different forms. This is apparent from the way rulers define nationality, the criteria for access to citizenship, national identity, differentiating and privileging citizen rights, presenting rights as a 'gift' of the ruler, and increasingly, punishing opponents by revoking their citizenship. Here inclusion and exclusion are the tools of politics. The examples Zahra Babar and Zeineb Alsabeehg give of contestation relate to women's right to pass their citizenship on to their children, minority rights, and freedom of expression, and, most significantly, revocation of citizenship, leaving opponents of the regime stateless. These issues are tied up with national identity and belonging, split identities, dual nationalities on the one hand, and rulers' strategies for regime survival, on 
the other. It shows that while rulers have been forced to make concessions with regard to major issues such as passing citizenship to children, any attempt to deepen citizenship and create active citizenship to challenge content is punished by the ultimate sacrifice of revocation of citizenship.

In Chapter 7 Nathalie Bernard-Maugiron shows that bringing about a new social contract after the Arab Uprisings was highly problematic and a key challenge to the political processes in the immediate post-Uprising situation. The old regimes had lost their popular legitimacy, but how should a new social contract be reflected and formulated in a constitutional language? While in Tunisia a near consensus on a new constitution was reached by the Constituent Assembly in January 2014 and free and fair elections organised in October that year, in Egypt - which is Maugiron's case study - the process failed to be inclusive and consensual. She compares the drafting process of the Constitution of 2012 under President Muhammad Morsi with the 2014 Constitution drawn up under Abd al-Fattah al-Sisi. Both were exclusive; the first dominated by Islamists, the second by opponents of the Muslim Brotherhood as represented in the 'Committee of 50' appointed by the military. The latter was less focused on religion and more on securing state powers and was called 'a short-term political deal rather than a long-lasting social contract'. This shows that in Egypt, unlike in Syria or Iraq, authoritarianism was able to legally secure its position by determining the extent, content and depth of citizenship. But it was not just the deep state that was able to reassert itself. Rather, what Nathan Brown calls the 'Balkanization of the Egyptian state', determines the rights of Egyptians. The Constitution of 2014 greatly limited the scope of the people's sovereignty by restricting the citizenry to followers of the 'divinely revealed religions', privileging the position of the military, and sanctioning the complete independence of the judiciary, making it even less accountable to the people. Specific elements of citizenship rights were also determined by the direct references to the status of citizens in different contexts. For example, while the Constitution of 2014 claims to secure equal rights of citizens, it regards women's natural position as the home; it recognises autonomy of non-Muslims and the special status of Copts (not as equal citizens), and the provision of Article 2 of Islam as state religion negates the provision of equality, and limits freedom of religion to followers of 'revealed religions' (Muslims, Christians and Jews). ${ }^{26}$ On

26 See Rachel Scott, 'Citizenship, Public Order, and State Sovereignty: Article 3 of the Egyptian Constitution and the "Divinely Revealed Religions"' in The Crisis of Citizenship in the Arab World, eds. Roel Meijer and Nils Butenschøn (Leiden: Brill, 2017) 375-405. 
the whole, many provisions were vague, and much was left to legislation to determine the citizenship regime with regard to human rights and other matters. In the end, the repression of the Egyptian state installed a highly repressive citizenship regime, regardless of the constitutional provisions.

In the second part of the book the relationship between Islam and citizenship is analysed. It shows that Islamic movements have only recently contributed to modern notions of political citizenship. In Chapter 8 Roel Meijer argues that fully articulated concepts of political citizenship depend on the recognition of the political as an independent field of human activity. ${ }^{27}$ One of the characteristics of political Islam is that in its totalising ideological overreach politics is absorbed by religion and then diffused over ethics and religious practices. As a result of the eclipse of the political and denial of politics as independent activity separate from religion, extent, content and depth of political citizenship are not only defined in religious terms, they have become non-negotiable, non-debatable, and cannot be challenged in a rational manner in an open 'neutral' debate. Citizens in such movements as the Muslim Brotherhood have no rights, debates are restricted and dissent punished by banishment; leadership is unaccountable and political struggle is largely an issue of identity. Sayyid Qutb brings this trend to its logical conclusion by the absorption of all agency in God's sovereignty who determines extent, content, and depth of citizenship. In a nation-state, however, citizenship is a central issue, and subsequent thinkers were forced to address in a more realistic manner the fundamental relationship between citizen and state. The second General Guide of the Muslim Brotherhood, Hasan al-Hudaybi (1891-1973) was strongly opposed to the exclusionary doctrine of takfir and challenged the stark choice Qutb made between jihad and unbelief. Likewise, Yusuf al-Qaradawi (b. 1926) advocates the rationality of the fiqh of balances as an alternative to Qutb's jihadism. Younger generations go even further by liberating politics from Islam, either through the separation of the two, as Abdelwahhab El-Affendi advocates, or creating enough room for politics and citizenship to emerge through the method of the "purposes of the sharia' (maqasid al-shari 'a). Especially these last two routes show promising signs towards achieving an Islamic politics based on the sovereignty of the people, Islamic humanitarian ethics and inclusive, equal citizenship. In terms of extent, content, and depth, their discourse gives back agency

27 For more on citizenship and the Wasatiyya trend, see Jakob SkovgaardPetersen, 'Brothers and Citizens: The Second Wave of Islamic Institutional Thinking and the Concept of Citizenship' in The Crisis of Citizenship in the Arab World, eds. Roel Meijer and Nils Butenschøn (Leiden: Brill, 2017), 320-37. 
to citizens, creates civility, recognises pluralism and a new intellectual openness.

In Chapter 9 Zoltan Pall analyses Salafism, ${ }^{28}$ a current in Islam that denies the relevance of citizenship as a relationship between state and citizen within the context of the nation-state. Instead, Salafis hold a universal, 'de-territorialised' concept of citizenship that includes the whole umma. Pall calls Salafism 'grounded utopianism', grounded in the sense that Salafis are connected to real situations, utopian because they strive for a return to the ideal society of the first three generations of Muslims. Their objection to the nation-state is its concept of sovereignty of the people and its demand of loyalty to a non-religious entity, fragmenting the umma into smaller units. In Salafi thought, extent and the question of who belongs to the community is a religious question and is limited to members of their own religious group; content is based on creed ('aqida) and is focused on the purification of doctrine and the emulation of the life of the first three generations of Muslims, who are the most pious and pure and are regarded as examples of a perfect life; depth, or what Salafis call manhaj (programme or methodology), demands a deep commitment through da'wa, preaching, and such practices as 'commanding good and forbidding evil'. However, as Pall shows, their groundedness and the reality of local political, social, religious and economic circumstances forces Salafis to make choices and compromises concerning the societal role of citizens. He compares two situations that have forced Salafis to adopt different strategies: in the first case, Lebanon, Sunnis are alienated from the sectarian state and feel threatened by the collapse of Syria and seek solidarity with Sunnis in Syria and Kuwait in a revival of the Sunni umma in their struggle against Hezbollah; in the second case, Salafis in Kuwait are more integrated and seek support from the state to help consolidate their institutions and the spread of Salafism internationally. Both cases demonstrate that Salafism is as much a product of the citizenship regimes in the region and rapid and deep political processes of change as it is a reflection of doctrine.

In Chapter 10 Shirin Saeidi shows how citizenship works out in the case of Iran where citizenship acquires a deep ambivalence due to, on the one hand, its revolutionary legacy and sense of agency and rights that its founders Shariati and Khomeini have given to the people, and, on the other hand, the current repressive power of the state that demands obedience. Whereas Salafism mostly denies a discourse of rights, the

28 See for more on citizenship and Salafism, Emin Poljarevic, 'The Ambiguity in Contemporary Salafism,' in The Crisis of Citizenship in the Arab World, eds. Roel Meijer and Nils Butenschøn (Leiden: Brill, 2017), 338-74. 
strong revolutionary strain of (gnostic) 'critical thinking' in contemporary Shi ism together with a much stronger rational philosophical dimension supports agency and acts of citizenship in Iran. It is the element of resistance in the service of the community and claim-making against the state that produces the notion of the citizen. The other element that works in favour of citizenship is the acceptance of a bounded entity of the Republic as a religious nation-state which clearly lays down specific relations between citizens and the state in a constitutional setting giving citizens equal rights. A third element that contributes to the strong ambivalence of citizenship rights in Iranian society is piety as a source of legitimacy and power. The idea that those who are more pious than others also have more rights - the same basis of Salafism (belonging to the 'saved sect') - lays the foundation for a hierarchy of rights and the rule of a religious elite over the majority of the people. This ambivalence between claims of citizens and their subjection to state power and state sanctioned pious hierarchy is reproduced in the Constitution. On the one hand it has a section on the 'The Rights of the People' who are called upon to defend the independence of the Republic, whereas on the other hand it stresses obedience to the state and respect for the religious political order. In the end, however, Saeidi argues it is not just rights per se that constitutes the potential for citizens to act and give them agency, it is the sovereignty of God that stands above the state that allows citizens to hold the state accountable to a supreme entity. This empowering principle has, of course, also operated in Europe during the Reformation, and in the Middle East has given Sayyid Qutb the power to develop jihad as a struggle for hakimiyya (sovereignty of God) against the secular state. In the second part of the chapter Saeidi gives several examples of how citizens have turned the more democratic principles of the Republic against it, both in its cultural institutions and in such highly ideologically loaded subjects as marriage, in this manner 'pushing the boundaries of autonomy and equality'.

The third part of the book focuses on the international dimensions of citizenship. In Chapter 11 Ruth Hanau Santini analyses the effect of policies of the European Union (EU) towards the Middle East and North Africa on extent, content and depth of citizenship. In the first half of the chapter she argues that the EU, due to the diversity of the political background of its own member states, political inertia, and attempts to depoliticise democracy and make it non-controversial and exportable, never developed a coherent policy towards the Middle East and North Africa (MENA) region promoting democracy. The result has been that the EU pursues a policy that is unfavourable to citizens of MENA, supporting a neoliberal policy that undermines the agency of citizens. Hanau Santini differentiates between two models: Protective Liberal Democracy, 
which the EU promotes, and Developmental Liberal Democracy, which is more rooted in the region but is far too activist for the EU. Whereas the first supports individualist liberalism, procedural democracy, the market economy and a passive concept of citizenship, the second assigns a greater role to the state and advocates an active, participatory citizenship and is more substantive, or what has been called a 'thick' citizenship. It also acknowledges the importance of social and economic rights. In the second half of the chapter Hanau Santini analyses in greater detail the instruments the EU has developed, such as the European Neighbourhood Policy (ENP), the European Instrument for Democracy and Human Rights (EIDHR) and the European Endowment for Democracy (EED). Despite the new policy of promoting 'deep democracy', Hanau Santini argues that new measures of the EU based on human rights, good governance, civil liberties, fair and free elections, the rule of law, or what should be regarded as a 'thin' concept of citizenship, did little to support the Arab countries in their citizenship revolutions after the Arab Uprisings.

In Chapter 12 Peter Seeberg analyses the position of the refugees from the civil war in Syria within the notion of citizenship and 'migration diplomacy'. Basically he analyses the agreement between the EU and Turkey of March 2016 in which Turkey grants Syrian refugees certain rights to have access to the Turkish labour market and provides certain services to refugees in the form of health care and education paid for by the EU (social and economic rights) in return for keeping Syrian refugees in Turkey and gradually integrating them into Turkish society. This agreement, which directly determines extent, content and depth of refugee status, provides a unique insight into citizenship policies of both the EU and Turkey and confirms the idea that citizenship is central to the current transformations in the Middle East. Seeberg argues that the refugee crisis has led to a greater interdependence between the EU and Turkey and greater complexity in their relations. In his words, it can lead to new a 'security partnership', but perhaps as important it confirms what Ruth Hanau Santini in the previous chapter points out: the EU's inability to develop a more substantive foreign citizenship policy is a reflection of its inability to formulate a common democratic internal one. In the case of the refugees, the EU's foreign citizenship policy can be regarded as a 'deferred' or 'transmitted' citizenship policy, allowing the Turkish government to determine the issues of extent, content and depth of the refugee problem rather than having the courage to organise that debate internally. The end result seems to be that the position of refugees has been far from settled and has become dependent on a power struggle between the EU, especially Germany, and Turkey. In this struggle, Erdoğan uses the refugee crisis as a lever to gain power over the EU and increase his popularity with his 
electorate. The Turkish electorat was promised to be able to travel freely without visas in Europe, while the refugees have acquired a second class status in Turkish society as a cheap labour force and are held hostage as a political instrument to exert pressure on the EU. Vague terms such as 'harmonisation', with which the governing party AKP describes the process of integration, remain too ambiguous to indicate clear rights.

In Chapter 13 Lillian Frost and Musa Shteiwi highlight the refugee crisis and integration of refugees as citizens from a different angle. They analyse the position of Syrian refugees in Lebanon and Jordan with regard to content and social rights to education, health and work, as well as political participation. In contrast to Turkey, refugees in these two countries are less dependent on the power politics of a single politician in an economically strong country. Frost and Shteiwi analyse these refugees as 'non-citizens', whose rights are defended by international organisations in the context of two different local citizenship regimes. Lebanon and Jordan have developed their refugee policies against the background of the position of their own citizens and their local citizenship regimes. In the case of Lebanon, this is sectarianism and a weak state, whose capacity of interference and enforcement is limited. As a result, refugees have few formal rights, depend on the welfare of different religious groups and the development of informal relations for survival, finding a job and acquiring access to health and educational services. In Jordan, where the state is sovereign, relatively strong and centralised, the refugee regime is mostly determined by the Palestinian-Trans-Jordanian divide. The refugees benefit from a regime used to distributing welfare and providing for social rights. In both states the demographic factor weighs strongly and determines to a large degree the issue of extent (who belongs to the political community) and political rights. In Lebanon, refugees cannot be integrated and become citizens because it would upset the demographic weight in favour of the Sunnis who would become a majority. In Jordan, they cannot become citizens because they do not belong to the Trans-Jordanian tribal support group of the monarchy. Other factors of influence are the weak economic basis of these countries and insufficient resources to cope with such large numbers of refugees, and increasingly since the 2011 securitisation. Frost and Shteiwi show in the second part of their chapter the influence international treaties and international law have on the position of refugees as non-citizens and how it affects their civil, political and economic rights.

In Chapter 14 Valerie Moghadam shows how globalisation has affected the economic rights of women in the Middle East and North Africa. While Frost and Shteiwi looked at the civil, social and economic rights of noncitizens, Moghadam analyses economic rights of women and investigates what chances women have in MENA to achieve economic citizenship. Her 
conclusion is that women have played a minor role in determining extent, content and depth of citizenship when it comes to their economic rights. In the first part of the chapter she analyses economic rights to employment and the right to freely find work of one's choice, which are hampered by patriarchy, family conventions and domestic duties; the second part deals with the effect the political economy has on women's rights. Rather than the so-called authoritarian bargain between authoritarian states and citizens, Moghadam argues that women were subjected to the 'patriarchal gender contract' which has kept women restricted to the household allowing men to become breadwinners. This arrangement was further supported by Islamic law, which strengthens patriarchal relations despite the many reforms of family law in the region. The weakening of the state and the introduction of the neoliberal economy in the 1980s further weakened existing economic rights of women. In the third part of the chapter Moghadam analyses the economic position of women on the eve of the Arab Uprisings. She shows that their position was much weaker than in other parts of the world in terms of labour participation. Women were also more highly concentrated in community, social and public services, leading to what she calls a 'feminisation of unemployment'. The final part of the chapter deals with women's organisations supporting women's economic rights. These were especially active in the Maghreb and it is there that women are able to exert some influence on the extent, content and depth of economic citizenship. 
Nils A. Butenschøn and Roel Meijer - 9781788111133 Downloaded from PubFactory at 04/26/2023 09:16:07AM 